\title{
Zaupanje kot faktor kohezije športnega tima
}

\author{
Igor Ivašković* \\ Univerza v Ljubljani, Ekonomska fakulteta, Kardeljeva ploščad 17, 1000 Ljubljana, Slovenija \\ igor.ivaskovic@ef.uni-lj.si
}

\begin{abstract}
Povzetek:
Raziskovalno vprašanje (RV): Kakšno vlogo in kako močan vpliv ima zaupanje v soigralce in zaupanje v trenerja na kohezivnost športnega tima?

Namen: Namen je prispevati k teoriji menedžmenta človeških virov s pojasnjevanjem odnosov med zaznavo kakovosti MČV, zaupanjem v sodelavce in nadrejenega ter timsko kohezivnostjo $\mathrm{v}$ športu. $\mathrm{Na}$ temelju teorije je razvit model, njegova veljavnost pa preverjena v praksi.

Metode: Model je bil testiran na podatkih, zbranih pri 559 košarkarjih iz 73 klubov, in sicer z modeliranjem strukturnih enačb. Uporabljen je tudi Sobelov test učinka posredovanja.

Rezultati: Zaupanje športnikov $\mathrm{v}$ trenerja in $\mathrm{v}$ soigralce neposredno pozitivno vpliva na raven kohezivnosti tima. Percepcija kakovosti MČV močno neposredno pozitivno vpliva na zaupanje v trenerja, ne pa tudi neposredno na kohezivnost ali na zaupanje $\mathrm{v}$ soigralce. Kljub temu se pozitiven učinek percepcije MČV posredno preliva preko zaupanja športnikov v trenerja na njihovo zaupanje v soigralce, posredno pa tudi povečuje stopnjo kohezivnosti tima.

Organizacija: Študija ponuja novo lestvico za merjenje percepcije kakovosti MČV. Opozarja trenerje na nujnost zavedanja pomembnosti zaupanja, ki ga uživajo med športniki, saj je to generator tako zaupanja med samimi športniki kot tudi kohezivnosti.

Družba: Študija poudarja pomen medosebnih odnosov in pojasnjuje, kako ljudje svoje zaupanje pretvarjamo v občutek boljše povezanosti s sodelavci.

Originalnost: Nova lestvica za merjenje percepcije kakovosti dela z ljudmi pri delu. Prva raziskava odnosa kakovosti MČV , dveh timskih relacij zaupanja in kohezivnosti športne ekipe.

Omejitve/nadaljnje raziskovanje: Uporaba subjektivnih podatkov in njihovo zbiranje v samo eni časovni točki. Priporočamo nadaljnje raziskave med športnimi klubi skozi daljše časovno obdobje, $\mathrm{v}$ različnih okoljih in v različnih športnih panogah.
\end{abstract}

Ključne besede: menedžment človeških virov, kohezivnost, košarka, tim, trener, zaupanje.

\section{Uvod}

Zaupanje in kohezivnost znotraj organizacije se obravnavata kot ključna vzvoda za doseganje celotnega spektra organizacijskih ciljev, kar velja tudi v športu (Mach, Dolan, \& Tzafrir, 2010, str. 771). Stopnja kohezije v ekipi in zaupanja med njenimi člani sta neke vrste »skupna imenovalca« pri ocenjevanju učinkovitosti menedžmenta človeških virov (MČV), saj ju želi doseči večina športnih ekip ne glede na raven tekmovanja, stopnjo profesionaliziranosti in ostale parametre, po katerih se športni klubi razlikujejo. Le-to je prepoznala tudi množica strokovnjakov, kar je v zadnjih petnajstih letih povzročilo izjemno rast števila raziskav na področju medosebnih odnosov v športnih ekipah. Kljub temu pa se še vedno večina študij osredotoča na posledice teh dveh konstruktov, manj raziskav pa odkriva njihove antecedense. 
S tega vidika so predvsem redko preučevani evropski športni klubi, kjer so timi sestavljeni iz profesionalnih in amaterskih športnikov. Dvojna struktura, v kateri je le del članov plačan, lahko implicira potencialne konflikte in otežuje doseganje zaupanja ter kohezivnosti v timu. Ambicija tega prispevka je zato storiti korak naprej v procesu razkrivanja tako imenovanega »black box« področja in preveriti, kakšno vlogo igra konstrukt zaupanja pri ustvarjanju kohezije $\mathrm{z}$ vidika MČV. Pri tem nas zanima predvsem, kako percepcija kakovosti MČV pri športnikih na ravni tima vpliva na dva ključna dejavnika t. i. »team-buildinga«. Osnovni cilj je razviti model za obravnavanje odnosov v trikotniku MČ V, zaupanje in kohezija ter ga nato preučiti z uporabo pridobljenih podatkov med samimi športniki. S pomočjo teorije socialne izmenjave poskušamo prispevati k boljšemu razumevanju odnosa med opazovanimi spremenljivkami, obenem pa preveriti, ali je teorija uporabna tudi za pojasnjevanje procesov v nepridobitnih organizacijah, kljub določenim kritikam, da naj bi reducirala medčloveške odnose na raven ekonomskih transakcij (Zafirovski, 2005, str. 15). S praktičnega vidika prispevek lahko koristi menedžmentu športnih klubov in trenerjem pri njihovih prizadevanjih za povečevanje medsebojnega zaupanja in kohezivnosti v športnih timih.

\section{Teoretična izhodišča}

Raziskovanje kohezivnosti se je do sedaj večinoma osredotočalo na njeno merjenje v skupinah in njenem vplivu na končni rezultat. Še vedno je relativno malo študij, ki bi poskušale identificirati dejavnike kohezivnosti. Le-te ugotavljajo, da je konstrukt zaupanja pomemben stimulator za tako za socialni kot opravilni vidik kohezivnosti. Posebej močna se je izkazala povezava med zaupanjem in delovno-opravilno komponento kohezije, ki je v več primerih bila potrjena kot pomembnejša dimenzija kohezivnosti v športnih timih, ki so fokusirani ravno na opravljanje določene skupne naloge (Mach, Dolan, \& Tzafrir, 2010, str. 771). Medtem ko je kohezija skupinski pojav, se lahko zaupanje vzpostavi v odnosu ene osebe do druge, do kraja, dogodka, predmeta, celo do več subjektov hkrati (Johnson-George \& Swap, 1982, str. 13061308), med dvema ali več organizacijami (Gulati, 1995, str. 108), med skupino in organizacijo (Zaheer, McEveily, \& Perrone, 1998, str. 141) itd. Z drugimi besedami, zaupanje je odvisno od pojava, kar implicira nujnost analize z različnih vidikov, odvisno od odnosa, ki se ga obravnava (Laeequddin, Sahay, Sahay, \& Waheed, 2010, str. 53-54). Zaupanje ima lahko več žarišč znotraj enega tima. To pomeni, da je kohezija običajno merjena na ravni celotnega moštva, medtem ko se zaupanje meri v okviru razmerja dveh subjektov. V literaturi s področja športa lahko opazimo poudarjanje pomembnosti distinkcije med dvema razmerjema znotraj tima, in sicer zaupanjem med športniki in zaupanjem športnikov v glavnega trenerja (Mach, Dolan, \& Tzafrir, 2010, str. 771). Druga razlika med kohezijo in zaupanjem se nanaša na dejstvo, da je zaupanje konstrukt znotraj osebe, ki ga vzpostavi v odnosu do druge osebe ali skupine oseb. Na drugi strani je kohezija dojemanje, kako se člani skupine obnašajo znotraj skupine v odnosu do drugih članov in do skupne delovne naloge.

Občutek zaupanja $\mathrm{v}$ druge organizacijske subjekte je $\mathrm{v}$ pozitivni povezavi $\mathrm{z}$ vedenjem na delovnem mestu in tudi s percepcijo kakovosti MČV sistemov v dotični organizaciji. Tzafrir 
(2005, str. 1600) ugotavlja, da zaupanje spodbuja izvedbo in učinkovitost nekaterih MČV praks in obratno. V literaturi lahko najdemo empirične dokaze, da imata MČV in zaupanje podobne pozitivne učinke na vedenje pri delu, na občutek pripadnosti organizaciji, na učinkovitost pri delu, na odprto komunikacijo, na pripadnost timu in ne nazadnje tudi na ekipno uspešnost (Dirks \& Skarlicki, 2009, str. 138). Raziskave tudi potrjujejo, da pozitivna percepcija kakovosti MČV in visoka stopnja zaupanja povzročata podobne posledice in pozitivno vplivata na organizacijsko uspešnost (Becker \& Huselid, 1998, str. 92-93; Mach, Dolan, \& Tzafrir, 2010, str. 771). Vendar je še vedno nejasno, v katero smer povezava med zaznavanjem MČV in zaupanjem deluje. Ta vzročno posledična relacija ima po vsej verjetnosti vzroke in učinke v obeh smereh, a MČV sistem in prakse običajno obstajajo, še preden posameznik postane član določenega organizacije. Kot navajata Searle in Skinner (2011, str 4.): »Naloga MČV je strukturiranje interakcij med ljudmi v organizaciji, da bi povečali učinkovitost.« MČV določa okvir, v katerem se bolj ali manj uspešno vzpostavljajo odnosi zaupanja. Učinkovitost pretoka informacij od menedžmenta do drugih organizacijskih članov je odvisna od lastnosti MČV sistema. Zato je slednji odgovoren tudi za ohranjanje dobrih medčloveških odnosov v organizaciji, kar vključuje izgradnjo zaupanja med organizacijskimi člani. Čeprav je zelo verjetna domneva, da zaupanje tudi vodi k boljši percepciji MČV, je vendarle na podlagi zdravorazumske interpretacije teorije socialne izmenjave, po kateri je interakcija pogoj za zaupanje, močnejša vzročno-posledična povezava v smeri od percepcije MČV proti zaupanju. MČV namreč vpliva na več dejavnikov zaupanja, in sicer tako na sposobnosti, integriteto, dobrohotnost in tudi na predvidljivost (Jackson \& Schuler, 1995, str. 239). V skladu s tem je smiselno predvidevati, da specifične MČV prakse v športnih klubih igrajo vlogo "zunanjega stimulatorja", ki vpliva na percepcijo kakovosti MČV med športniki in nato na njihovo zaupanje v druge organizacijske subjekte.

Hipoteza 1: Percepcija kakovosti MČV ima neposredni pozitivni učinek na stopnjo zaupanja med športniki znotraj tima.

Hipoteza 2: Percepcija kakovosti MČV ima neposredni pozitivni učinek na stopnjo zaupanja športnikov v trenerja.

$\mathrm{Z}$ ozirom na to, da športniki in trener nimajo enakih pristojnosti in odgovornosti za izvajanje MČV, je razumno pričakovati, da bo se bo vpliv percepcije kakovosti MČV med tema dvema razmerjema razlikoval v skladu s pristojnostjo in odgovornostjo tistega subjekta, $v$ katerega zaupanje merimo. Glavni trener je tisti organizacijski subjekt, ki ima najvišjo stopnjo pristojnosti in odgovornosti pri vsakodnevnih MČV aktivnostih, ki jih športniki občutijo. Ima običajno precej manevrskega prostora za oblikovanje karakterja MČV sistema, zato je ravno on (vsaj z vidika športnikov) najpomembnejši organizacijski subjekt za izvajanje MČV politik kluba, medtem ko športniki le sodelujejo v izvedbeni fazi. V skladu s to predpostavko bi moral trener dobiti največji del hvale ali graje s strani športnikov zaradi dobrega ali slabega načrtovanja in izvajanja MČV praks. To posledično pomeni, da bi morala percepcija kakovosti 
MČV v večji meri vplivati na zaupanje športnikov v glavnega trenerja kot na stopnjo zaupanja med samimi športniki.

Hipoteza 3: Percepcija kakovosti MČV ima močnejši učinek na stopnjo zaupanja košarkarjev $\mathrm{v}$ trenerja kot na zaupanje med športniki znotraj tima.

V skladu s teorijo socialne izmenjave so organizacije forumi za družbene (in ekonomske) transakcije (Cropanzano, Prehar, \& Chen, 2002, str. 327). Po tej teoriji je tudi uspešnost tima posledica interakcije, usklajevanja in sodelovanja med člani moštva (Hackman \& Morris, 1975, str. 6), pri čemer naj bi ravno zaupanje predstavljalo ključni dejavnik v procesih družbene menjave (Blau, 1964, str. 88-97). V okviru športne ekipe zaupanje omogoča posameznemu športniku pozitivne zaznave in občutke glede drugih članov tima in mu hkrati omogoča odprtost, zanesljivost in skrbnost. To naj bi spodbudilo cikel krepitve pozitivnih učinkov v ekipi, kar bi lahko med drugim povzročilo tudi rast stopnje ekipne kohezivnosti. Manifestacija visoke stopnje zaupanja se pojavi v času povečanega tveganja. V kritičnih trenutkih zaupanje vpliva na člane skupine, da sprejmejo svojo vlogo in izvedejo tudi tiste neprijetne naloge, ki so potrebne za uspešnost skupine (Dirks, 2000, str. 1009). Zaupanje zagotavlja občutek, da lahko en član ekipe predvidi in razume druge. Obenem pomaga zmanjšati zaznavanje tveganja, ranljivosti in negotovosti, kar omogoča članom tima osredotočanje vsak na svojo nalogo v okviru timskega dela. Na drugi strani je bilo ugotovljeno, da tisti, ki ne zaupajo v druge člane lastne organizacije, delajo manj učinkovito (Dirks \& Ferrín, 2001, str. 455). Pozitivna povezava med zaupanjem in kohezijo je bila potrjena v prejšnjih študijah (Lu, 2015, str. 58), tudi z vidika timskih športov (Mach, Dolan, \& Tzafrir, 2010, str. 771). Posledično postavljamo sledeči hipotezi.

Hipoteza 4: Zaupanje med športniki neposredno pozitivno vpliva na percepcijo timske kohezije.

Hipoteza 5: Zaupanje športnikov v trenerja neposredno pozitivno vpliva na percepcijo timske kohezije.

V skladu z do sedaj navedeno argumentacijo bi bilo smiselno napovedati pozitiven odnos med percepcijama kakovosti MČV in kohezijo. Tudi prejšnje raziskave so ugotovile, da sta percepcija MČV in kohezija v korelaciji z enakimi konstrukti, in sicer: zaupanjem (Tzafrir, 2005, str. 1600), organizacijskim uspehom (Becker \& Huselid, 1998, str. 92-93) in športnim rezultatom (Mach, Dolan, \& Tzafrir, 2010, str. 771). MČV sistem je odgovoren za ohranjanje dobrih medčloveških odnosov v organizaciji in ima nalogo spodbujati skupino ljudi pri čim učinkovitejšem uresničevanju namena organizacije. Slednja teza je zelo blizu Carronove in Brawleyjeve (2000, str. 94) opredelitve kohezivnosti, zato lahko sklepamo, da bi morala ena izmed funkcij MČV biti tudi doseganje visoke stopnje kohezije v moštvu. Po drugi strani je zanimivo, da je do sedaj bila dokazana le posredna pozitivna povezava med percepcijo MČV in ekipno kohezijo. Pri tem seveda ne smemo pozabiti, da je percepcija kohezivnosti subjektivna zaznava, kako dobro člani skupine sodelujejo. Zato je ekipna kohezivnost vedenjska posledica miselne spremembe znotraj posameznih članov skupine in ne primarna 
posledica percepcije MČV. To nakazuje, da sta morda zaznana kakovost MČV in timska kohezija v posredni vzročno-posledični povezavi, ki ju povezuje tretji konstrukt emocionalne narave. Zaupanje se s tega vidika zdi primeren dejavnik, ki bi lahko igral vlogo mediatorja v razmerju MČV - kohezivnost, saj je pričakovan dejavnik kohezivnosti in pričakovana posledica percepcije kakovosti MČV. Tudi prejšnje študije poročajo o povezavi med vedenjem trenerja in kohezivnostjo (Crciun \& Rus, 2009, str. 217), zato lahko predpostavimo, da zaznavanje kakovosti MČV pozitivno vpliva na zaupanje športnikov v tiste subjekte, ki so odgovorni za njegovo izvajanje, in da zaupanje ta učinek transferira na zaznavo ekipne kohezivnosti. V skladu s tem predlagamo zadnji dve hipotezi.

Hipoteza 6: Zaupanje športnikov $\mathrm{v}$ trenerja posreduje pozitivni učinek med percepcijo kakovosti MČV na percepcijo timske kohezije.

Hipoteza 7: Zaupanje med športniki znotraj ekipe posreduje pozitivni učinek med percepcijo kakovosti MČV in percepcijo timske kohezije.

\section{Metoda}

\subsection{Tehnike}

$\mathrm{V}$ prvem delu analize so bile psihometrične lastnosti merjenih spremenljivk preverjene $\mathrm{s}$ konfirmatorno faktorsko analizo (CFA), notranjim koeficientom konsistentnosti (ICC) in izračunom Cronbachovih alf. Nato smo analizirali podatke $\mathrm{z}$ uporabo korelacijske analize, strukturnega modeliranja enačb (SEM) in Sobelovega testa posredovanja učinka.

\subsection{Vzorec}

Zbiranje podatkov je potekalo med košarkarji na področju štirih držav, in sicer Slovenije, Hrvaške, Bosne in Hercegovine ter Srbije. Košarka ima dolgo tradicijo v vseh omenjenih državah, obenem pa klube, ki delujejo v teh državnih tekmovanjih, po njihovi velikosti in letnih proračunih lahko smatramo kot reprezentativne tudi za klube v drugih panogah. Želeli smo vključiti tudi ostale post-tranzicijske države jugovzhodne Evrope, a smo le pri omenjenih naleteli na podporo panožnih zvez pri zbiranju podatkov. $\mathrm{V}$ času zbiranja podatkov je $\mathrm{v}$ štirih državah skupno v državnih prvenstvih sodelovalo 249 klubov. 73 jih je pristalo na sodelovanje, kar je $29 \%$ (skupno je pridobljenih 559 izpolnjenih anket košarkarjev). Udeleženci so bili v povprečju stari 22,17 let $(S O=4,73)$ in so imeli v povprečju 4,81 let $(S O=4,62)$ izkušenj z igranjem za trenutni klub $\mathrm{v}$ članskih tekmovanjih. S trenutnim trenerjem so košarkarji do izvedbe anketiranja v povprečju sodelovali 2,45 let $(S O=2,49)$.

\subsection{Spremenljivke}

Kohezivnost. Uporabili smo »Group Environment Questionnaire« (GEQ), ki so ga razvili Carron, Widmeyer in Brawley (1985, str. 248-251). Izvirni vprašalnik vsebuje 18 vprašanj in ocenjuje štiri vidike kohezije, in sicer: "posameznikovo sprejemanje skupinske naloge«, "posameznikovo sprejemanje skupine kot družbe«, »posameznikovo percepcijo privlačnosti naloge za celotno skupino« in »posameznikovo percepcijo družbene integracije znotraj 
skupine«. Carron in Brawley (2000, str. 100-103) sta v preteklosti predložila dokaze o veljavnosti vprašalnika in utemeljila njegovo primernost za uporabo med športnimi timi. Li in Harmer (1996, str. 49) pa sta v svojem primeru izvedla tudi faktorsko analizo, ki je potrdil veljavnost GEQ. Vendar sta slednja v skladu s kritiko Hogga, Abramsa, Otten in Hinkla (2004, str. 246-247) uporabila le dve komponenti prvotnega vprašalnika, in sicer tisti, ki sta se nanašali na opravilo oziroma nalogo. Z ozirom na dejstvi, da se tudi ta študija osredotoča na time, ki stremijo k uspešnem opravljanju nalog, ter da so predhodne študije med košarkarskimi in drugimi športnimi timi večkrat potrdile, da imata drugi dve komponenti kohezije bistveno manjši vpliv na uspešnost moštev (Carron, Bray, \& Eys, 2002, str. 121; Carron \& Brawley, 2000, str. 95), so v vprašalniku izpuščena tista vprašanja, ki se nanašajo na merjenje socialne komponente kohezivnosti. Percepcija kohezivnosti je bila pri košarkarjih merjena na 7stopenjski Likertovi lestvici, pri čemer sta ekstrema predstavljali ocena 1 (»sploh se ne strinjam «) in ocena 7 (»popolnoma se strinjam«). Cronbachova alfa devet vključenih trditev je znašala 0,77 , kar pomeni, da je kohezijska lestvica imela sprejemljivo raven zanesljivosti. Nato je bila izvedena CFA, in sicer z namenom preverjanja, ali konstrukt res tvorita dva faktorja. Rezultati niso podprli eno-faktorske strukture, saj so vsi indeksi primernosti bili pod pragom 0,9 . Poleg tega je koren povprečne kvadratne napake bil nad pragom 0,1 , kar kaže, da struktura modela ni predstavljala dovolj dobrega približka. Po drugi strani je dvofaktorska struktura (CFI $=0,96 ; N N F I=0,93 ; N F I=0,94 ; R M S E A=0,06)$ dosegla bistveno boljši rezultat primernosti $\mathrm{v}$ vseh parametrih in zadovoljila pogoje sprejemljivosti modela $\mathrm{z}$ danimi podatki.

Zaupanje. Uporabili smo Adamsovo, Waldherrjevo in Sartorijevo (2008, str. 13-16) mersko lestvica, ki je bila razvita za merjenje zaupanja med skupinami vojakov, kjer so odnosi med člani podobni kot v športnih timih. Lestvico tvorijo štiri komponente: »dobrohotnost«, »integriteta«, "predvidljivost« in »sposobnost«. Vprašanja so bila za izvedbo te študije prilagojena košarkarskim klubom, stopnja zaupanja pa se je merila na dveh relacijah, in sicer zaupanje košarkarjev $\mathrm{v}$ soigralce in zaupanje košarkarjev $\mathrm{v}$ trenerja. Uporabili smo 7stopenjsko Likertovo lestvico, ki je imela ekstrema v točkah 1 (»s trditvijo se sploh ne strinjam《) in 7 (»S trditvijo se popolnoma strinjam«). S pomočjo CFA je bila preverjena struktura konstrukta. Rezultati niso podprli enofaktorske niti dvofaktorske strukture, vendar je slednja dosegla boljše vrednosti po vseh parametrih. Ker je originalni vprašalnik zaupanja vseboval štiri dimenzije, je bila opravljena CFA drugega reda tako, da sta model sestavljala dva faktorja drugega reda, vsak s štirimi faktorji prvega reda. Rezultati $(C F I=0,91 ; N N F I=0,89$; $N F I=0,89 ; R M S E A=0,08)$ niso bili idealni zaradi nekoliko nizkih vrednosti NNFI in NFI, vendar so bili sprejemljivi z CFI in RMSEA. Splošna zanesljivost lestvic zaupanja z vidika športnikov je bila zelo visoka. Cronbachova alfa za konstrukt zaupanja v soigralce je namreč znašala 0,91 , za konstrukt zaupanja $\mathrm{v}$ trenerja pa 0,95 .

Percepcija kakovosti $M \check{C} V$. Želeli smo razviti posebno lestvico, ki bi bila najbolj primerna za ocenjevanje občutkov in stališč pri košarkarjih. Zato je bila organizirana razprava, na katero je bilo povabljenih 11 košarkarjev in 11 strokovnjakov s področja MČV v športnih klubih (od tega je bilo pet glavnih trenerjev, pet športnih direktorjev in en športni psiholog), pri čemer je vsak 
imel vsaj pet let delovnih izkušenj v košarkarskih klubih na obravnavanem področju. Vsak član delovne skupine je dobil Gould-Williamsovo in Daviesovo (2005, str. 11-12 in 14-15) ter Gonçalvesino in Nevesovo (2012, str. 33-34) lestvico, nato je dobil nalogo, da jo preuči in parametre ocenjevanja kakovosti MČV prilagodi oziroma spremeni za posamezno raven anketiranja. Vsak član je imel možnost razviti svojo lestvico, ki jo je potem predstavil, končni seznam ključnih točk v vsaki od treh lestvic kakovosti MČV pa je posledica združevanja podobnih faz. MČV proces z vidika košarkarja je bil tako razdeljen na deset faz, in sicer: skavting in privabljanje, pogajanja pri pogodbenem razmerju, selekcija, trening, določanje igralne strategije, vodenje tekme, ocenjevanje uspešnosti, denarno nagrajevanje, nedenarno nagrajevanje in način zapuščanja kluba. Košarkarji so s pomočjo 7-stopenjske Likertove lestvice ocenjevali kakovost vsake posamezne faze $M \check{C} \mathrm{~V}$, kjer je višja ocena izražala večjo stopnjo zadovoljstva glede kakovosti MČV. Lestvica je bila zasidrana v ekstremu 1, ki je pomenil, da so "prakse $\mathrm{v}$ tej fazi MČV zelo slabo opredeljene, njihova izvedba pa je neučinkovita«. Nasprotno je pomenila ocena 7, da so »prakse v tej fazi MČV zelo dobro opredeljene in izredno kakovostno izvedene«. Da bi preverili strukturo merjenega konstrukta, je bila najprej izvedena bivariatna korelacijska analizo med percepcijami kakovosti deset MČV faz. Rezultati so pokazali, da je obstajala izredno visoka korelacija $(\mathrm{r}>0,7)$, $\mathrm{v}$ trikotniku spremenljivk »trening«, »igralna strategija" in »vodenje tekem«, medtem ko so ostali korelacijski koeficienti bili pod to vrednostjo. Še več - ravno med temi tremi spremenljivkami je bil pokazatelj multikolinearnosti VIF ("variation inflation factor") nad vrednostjo 3. To je predstavljalo indic, da obstaja možnost, da se te tri faze $\mathrm{z}$ vidika košarkarjev dejansko ne razlikujejo in predstavljajo skupno fazo MČV . Rezultati CFA so podprli 8-faktorsko strukturo $(C F I=0,99 ; N N F I=0,95 ; N F I=0,98 ; R M S E A=0,07)$, v kateri so omenjene tri faze oblikovale skupen faktor. Eno-faktorska in 10-faktorska struktura se nista pokazali kot primerni za ta nabor podatkov, saj so bili vsi indeksi primernosti pod zadovoljivim pragom, RMSEA pa je bila večja od še sprejemljive vrednosti 0,10 . Cronbachova alfa $(0,92)$ je potrdila zanesljivost novega skupnega faktorja treh združenih spremenljivk, medtem ko je skupna alfa za celotno 8faktorsko MČV lestvico dosegla vrednost 0,85 .

Slika 1 prikazuje položaj preučevanih spremenljivk v paradigmatičnem modelu. Ob tem pa sta v začetno analizo dodani še dve spremenljivki, ki bi lahko vplivali na preučevane relacije. V raziskavo smo dodali še »število let v ekipi« in »število let sodelovanja s trenerjem«, saj oboje lahko vpliva na določene komponente športnikovega zaupanja do članov tima. 


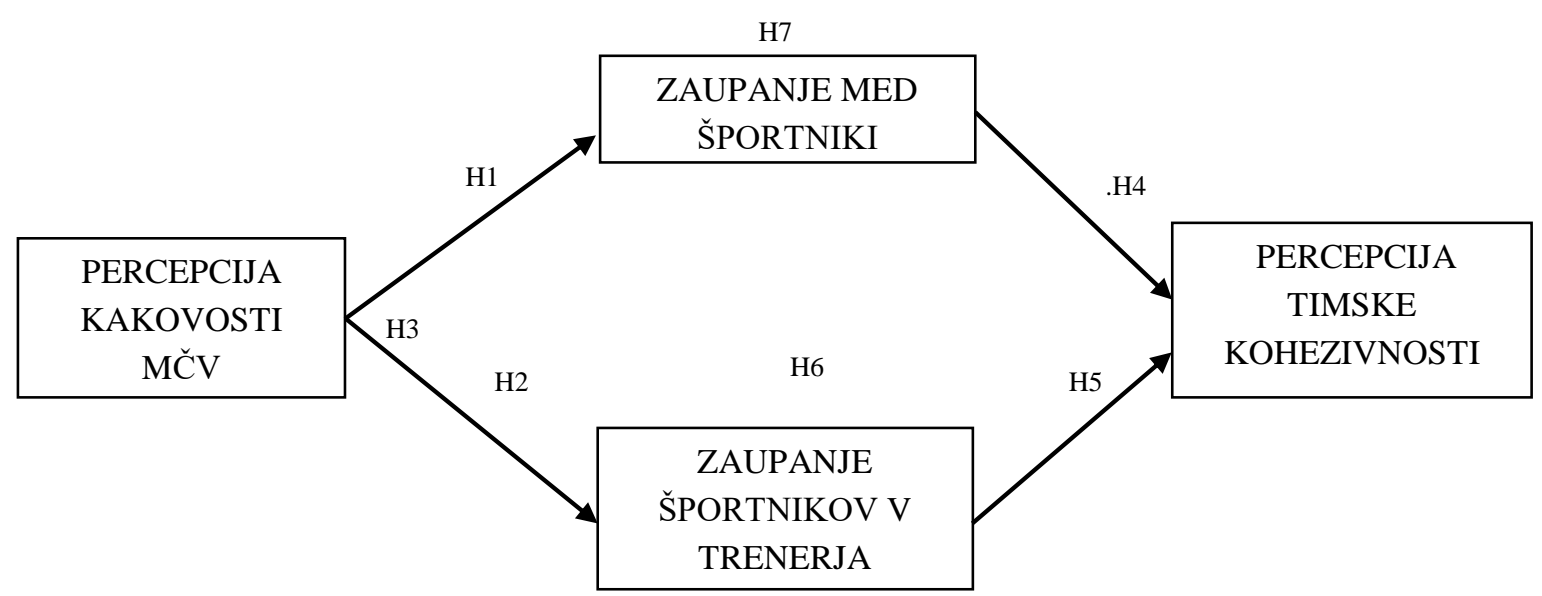

Slika 1. Paradigmatičen model.

\subsection{Predtestiranje}

Vsi podatki so pridobljeni pri istem viru informacij, zato je bilo potrebno upoštevati potencialne težave pristranskosti, in sicer CMB ("common method bias") in diskriminantno veljavnost. Najprej je bilo preizkušeno, kako se celotni model z vsemi latentnimi spremenljivkami prilega konkretnim podatkom glede na tri parametre: hi-kvadrat, CFI in RMSEA. Rezultati so pokazali zadovoljivo primernost modela za konkretno bazo podatkov $(\chi 2=1.693 ; d f=765 ; C F I=0,96$; $R M S E A=0,05)$. V naslednjem koraku je bil izveden še t. i. Harmanov test skupnega latentnega faktorja. V model je bil uveden nov skupni faktor, na katerega so se navezovale vse spremenljivke. Test takšnega modela je pokazal zelo slabo prileganje podatkom pri obeh vzorcih, kar pomeni, da en sam dejavnik ne more biti odgovoren za večino variance spremenljivk v danem modelu. Preverjanje razlikovanja konstruktov v hipotetičnem modelu je bilo izvedeno s preizkusom diskriminantne veljavnosti, in sicer s t. i. AVE ("average variance extracted"). Test je potrdil, da dane spremenljivke med seboj dosegajo zadovoljivo stopnjo različnosti.

Na koncu smo združili posamezne percepcije znotraj ekipe, in sicer tiste, ki so se nanašale ne zaznavo zaupanja, kohezije v ekipi in zaznane kakovosti MČV. Da bi upravičil združevanje, smo izvedli analizo ICC za vsako ekipo in vsako od navedenih spremenljivk posamezno. Koeficienti ICC so gibali 0,77 do 0,91, kar kaže na izredno visoko stopnjo zanesljivosti. Pri tem smo morali agregirati tudi dolžino sodelovanja košarkarjev s trenerjem in dolžino trajanja članstva košarkarja v prvi članski ekipi trenutnega kluba. ICC pri teh dveh spremenljivkah so pri nekaterih klubih razumljivo bili pod vrednostjo 0,4, saj ekipe običajno predstavljajo zmes starejših in izkušenejših košarkarjev $\mathrm{z}$ daljšim članskim stažem in obdobjem sodelovanja $\mathrm{s}$ trenerjem ter na drugi strani mlajših in manj izkušenih igralcev, ki so komaj začeli svojo člansko kariero ter so šele začeli sodelovati s trenutnim glavnim trenerjem. 


\section{Rezultati}

$\mathrm{Z}$ namenom jasnega prikaza razmerja med zaznano kakovostjo MČV, zaupanjem in kohezijo pri posameznikih je bila naprej izvedena korelacijska analizo za vse opazovane spremenljivke (tabela 1).

Tabela 1. Aritmetične sredine, standardni odkloni in korelacijski koeficienti $(\mathrm{N}=73)$

\begin{tabular}{|c|c|c|c|c|c|c|c|}
\hline Spremenljivka & AS & SO & 1 & 2 & 3 & 4 & 5 \\
\hline 1. Percepcija kakovosti MČV & 4,44 & ,66 & & & & & \\
\hline 2. Zaupanje med košarkarji: & 5,54 &, 52 &, $42 *$ & & & & \\
\hline a) Dobrohotnost & 5,80 &, 53 &, $38 *$ & & &, $46^{* *}$ & \\
\hline b) Integriteta & 5,58 &, 52 &, $31 *$ & & &, $62^{* *}$ & \\
\hline c) Predvidljivost & 5,20 &, 58 &, $50 * *$ & & &, $52 * *$ & \\
\hline d) Sposobnosti & 5,61 & 60 &, $38^{*}$ & & &, $64 * *$ & \\
\hline 3. Zaupanje $v$ trenerja: & 5,78 &, 74 &, $55^{* *}$ &, $65 * *$ & & & \\
\hline a) Dobrohotnost & 5,94 & ,80 &, $49 * *$ &, $61 * *$ & &, $43 * *$ & \\
\hline b) Integriteta & 5,92 &, 81 &, $51 * *$ &, $57 * *$ & &, $54 * *$ & \\
\hline c) Predvidljivost & 5,32 & ,66 &, $47 * *$ &, $70 * *$ & &, $50^{* *}$ & \\
\hline d) Sposobnosti & 5,93 & ,90 &, $60 * *$ &, $58 * *$ & &, $59 * *$ & \\
\hline 4. Kohezija & 4,89 & ,67 & ,22 &, $60 * *$ &, $55^{* *}$ & & \\
\hline 5. Leta v ekipi & 4,46 & 2,87 & 00 & ,07 &, 01 & ,13 & \\
\hline 6. Leta $s$ trenerjem & 2,21 & 1,45 &, 05 & , 14 & , 17 & , 16 &, $44^{* *}$ \\
\hline
\end{tabular}

Prvi rezultati SEM so pokazali, da se hipotetični model ni najbolje prilegal danim podatkom. Indeksi primernosti, in sicer CFI, NFI in NNFI, so vsi bili pod pragom 0,9 , medtem ko je bila napaka RMSEA precej nad še maksimalno ohlapno dopustno mejo 0,10 . Z ambicijo izboljšanja izhodiščnega modela je bil upoštevan predlog Alfesa in ostalih (2013, str. 848) o iskanju alternativnih modelov, ki bi $\mathrm{v}$ danih okvirih odražali bolj realno sliko vzročno-posledičnih povezav med opazovanimi spremenljivkami. Najprej smo preverili, ali obstaja neposredna povezava med percepcijo kakovosti MČV in dojemanjem stopnje kohezivnosti ekipe med košarkarji. $\mathrm{V}$ model 2 smo zato vključili neposredno povezavo med omenjenima spremenljivkama, vendar $\mathrm{v}$ skladu z rezultati $\mathrm{v}$ tabeli 2 ta modifikacija modela ni izboljšala njegove primernosti, ravno nasprotno. Tudi sam standardni regresijski koeficient med percepcijo kakovosti MČV in zaznavo kohezivnosti je bil statistično neznačilen, zato smo lahko dokončno opustili možnost neposrednega vpliva zaznave kakovosti MČV na stopnjo ekipne kohezivnosti. Nato je bila $v$ alternativni model 3 dodana neposredna povezava med zaupanjem košarkarjev v glavnega trenerja in zaupanjem med košarkarji. Delovanje te vzročno-posledične poti so potrdili Mach, Dolan, in Tzafrir (2010, str. 771), obenem pa je to tudi v skladu s posebno vlogo, ki jo ima trener v procesu formiranja ekipe, zlasti v procesu selekcije košarkarjev. Posledično naj bi višja stopnja zaupanja $\mathrm{v}$ glavnega trenerja in pravilnost njegovih odločitev vodila tudi $\mathrm{k}$ višji stopnji zaupanja v košarkarje, saj je njihovo članstvo ravno plod trenerjeve odločitve. Tokrat se je primernost modela bistveno izboljšala, rezultati pa so zadoščali za 
ugotovitev, da je model 3 je primeren odraz razmerij med opazovanimi spremenljivkami. Obenem je testiranje te različice modela pokazalo, da standardizirani regresijski koeficient med percepcijo kakovosti MČV in stopnjo zaupanja med košarkarji ni statistično značilen na ravni 0,05. Navkljub statistično značilni korelaciji med percepcijo kakovosti MČV in zaupanjem V soigralce neposredne statistično značilne vzročne zveze med tema dvema spremenljivkama očitno ni. Soigralci z vidika košarkarjev očitno niso nosilci oziroma izvajalci zaznanih MČV praks. Po Bowen in Guo (2011, str. 162) je potrebno strukturni model modificirati z izločitvijo neznačilnih povezav, če to podpira teorija. Zato je bila $\mathrm{v}$ četrti različici modela ta povezava odstranjena (slika 2). To je rezultiralo z dodatnim izboljšanjem primernosti modela. Da bi se prepričal v optimalnost te različice, je bilo izvedeno SEM tudi na vseh drugih alternativnih modelih razmerij med opazovanimi spremenljivkami, vendar noben ni pokazal boljših rezultatov prileganja danim podatkom.

Tabela 2. Rezultati SEM

\begin{tabular}{lcccccc}
\hline Model & $\boldsymbol{\chi 2}(\mathbf{d f})$ & $\mathbf{p}$ & CFI & NFI & NNFI & RMSEA \\
\hline Hipotetični & $56,983(36)$ &, 014 &, 92 &, 83 &, 88 &, 13 \\
Model 2 & $55,596(35)$ &, 015 &, 92 &, 83 &, 88 &, 13 \\
Model 3 & $45,179(35)$ &, 116 &, 96 &, 88 &, 94 &, 09 \\
Model 4 & $45,201(36)$ &, 140 &, 97 &, 89 &, 95 &, 08 \\
\hline
\end{tabular}

Opomba. $\chi^{2}$ - hi-kvadrat; df - »degrees of freedom«; CFI - »comparative fit index «; NFI - »normed fit index «); NNFI - »non-normed fit index «; RMSEA - »root mean square error of approximation«.

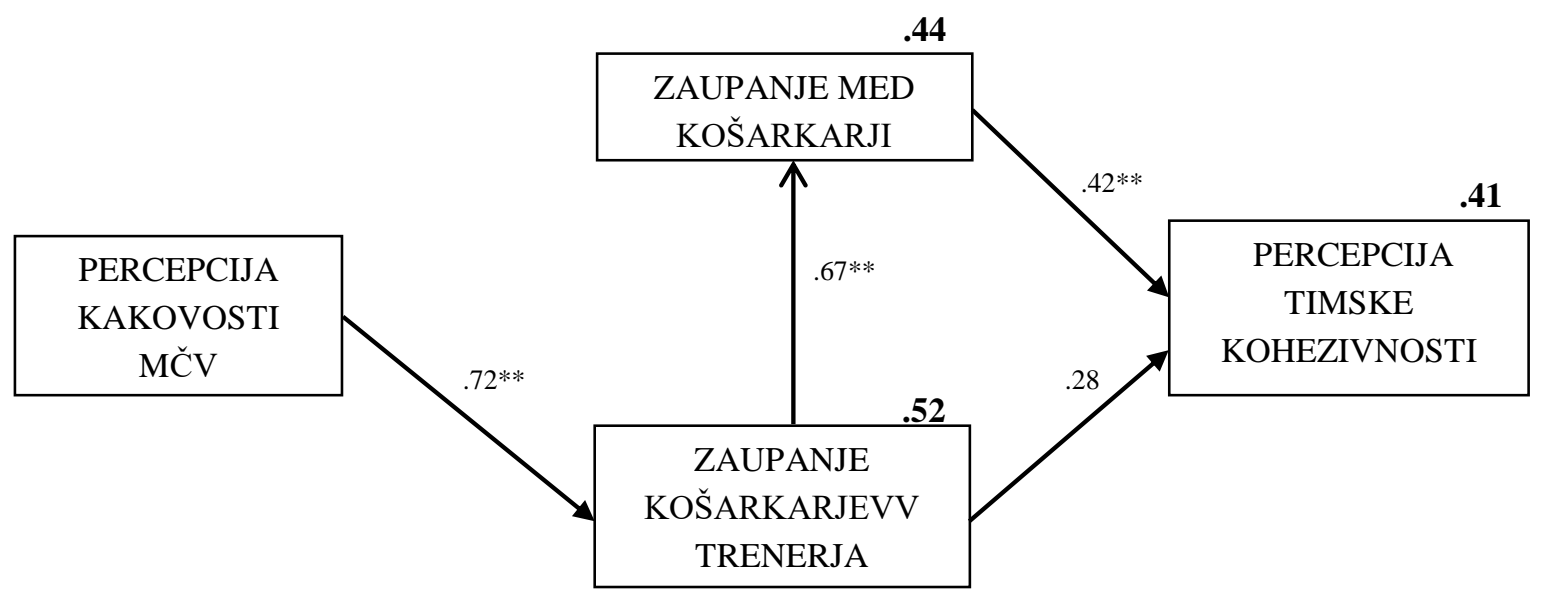

Slika 2. Rezultati SEM za model 4. Opomba. $* *-p<0,01 ; *-p<0,05$.

Z namenom preverjanja, ali dejansko obstajajo posredni učinki, ki jih implicira model 4, je bil izveden Sobelov test mediacije in serija regresijskih analiz. Rezultati, ki jih prikazuje tabela 3, potrjujejo, da percepcija kakovosti MČV res vpliva na zaupanje med košarkarji in ekipno kohezivnost, vendar le posredno preko konstrukta zaupanja košarkarjev v glavnega trenerja. 
Tabela 3. Testi mediacije za model 4

\begin{tabular}{|c|c|c|c|c|}
\hline Mediator & $\mathbf{X}$ & $\mathbf{Y}$ & Tip mediacije & Sobelov test \\
\hline $\begin{array}{c}\text { Zaupanje } v \\
\text { trenerja }\end{array}$ & $\begin{array}{c}\text { Percepcija } \\
\text { kakovosti MČV }\end{array}$ & $\begin{array}{c}\text { Kohezija } \\
\text { v timu }\end{array}$ & Posredna & $z=2,63 ; p=, 009$ \\
\hline $\begin{array}{c}\text { Zaupanje v } \\
\text { trenerja }\end{array}$ & $\begin{array}{c}\text { Percepcija } \\
\text { kakovosti MČV }\end{array}$ & $\begin{array}{l}\text { Zaupanje } \\
\text { med } \\
\text { košarkarii }\end{array}$ & Posredna & $\mathrm{z}=2,72 ; \mathrm{p}=, 006$ \\
\hline $\begin{array}{l}\text { Zaupanje med } \\
\text { košarkarji }\end{array}$ & $\begin{array}{l}\text { Zaupanje v } \\
\text { trenerja }\end{array}$ & $\begin{array}{l}\text { Kohezija } \\
\text { v timu }\end{array}$ & Posredna & $\mathrm{z}=2,13 ; \mathrm{p}=, 033$ \\
\hline
\end{tabular}

\section{Razprava}

Rezultati potrjujejo močan vpliv percepcije kakovosti MČV na stopnjo zaupanja košarkarjev v glavnega trenerja, kar je v skladu s hipotezo 2. Obenem napeljujejo na ugotovitev, da oba obravnavana konstrukta zaupanja na timski ravni močno vplivata na percepcijo kohezivnosti med samimi košarkarji, kar je v skladu s hipotezama 4 in 5. Kar $41 \%$ variance pri percepciji ekipne kohezivnosti je bilo namreč pojasnjeno s tema dvema dejavnikoma. Kljub temu pa je potrebno opozoriti, da neposredna relacija med stopnjo zaupanja košarkarjev v glavnega trenerja in zaznano stopnjo ekipne kohezije ni bila statistično značilna na ravni 0,05 ( $\beta=0,28$; $\mathrm{p}=0,10)$. Rezultati potrjujejo domnevo, da ima percepcija kakovosti MČV močnejši vpliv na raven zaupanja košarkarjev v glavnega trenerja kot na raven njihovega medsebojnega zaupanja, kar je bilo predvideno v hipotezi 3. Res je sicer, da rezultati niso ponudili dokaza o neposrednem vplivu percepcije kakovosti MČV na raven zaupanja med košarkarji, kar je v nasprotju s hipotezama 1 in posledično tudi 7. Ravno tako ni dokaza, da bi percepcija kakovosti MČV posredno vplivala na stopnjo kohezivnosti tima. Kljub temu pa je končni test posredovanja potrdil tri posredniške učinke v končnem modelu. Pri tem ima stopnja zaupanja košarkarjev v glavnega trenerja ključno posredniško vlogo v dveh primerih.

Rezultati so podkrepili tezo, da percepcija kakovosti MČV vpliva na zaupanje košarkarjev in ima posreden vpliv na njihovo percepcijo ekipne kohezije. S širšega vidika je pričujoča študija empirični dokaz, ki gre v prid splošni tezi, da boljša percepcija kakovosti MČV vodi do večje stopnje zaupanja znotraj športnih ekip. To je v skladu s predhodnimi ugotovitvami o pozitivnih relaciji med MČV in zaupanjem (Tzafrir, 2005, str. 1600) in s tezo, da je visoka stopnja zaupanja v povezavi ravno s pozitivnim zaznavanjem MČV (Condrey, 1995, str. 689). Istočasno rezultati kažejo, da percepcija MČV ne vpliva na enak način na različne relacije zaupanja znotraj ekip. Percepcija kakovosti MČV je namreč v pričujoči študiji na ekipni ravni na zaupanje med košarkarji vplivala le posredno, medtem ko je na zaupanje košarkarjev v glavnega trenerja vplivala izredno močno in neposredno. Ravno slednji konstrukt igra posredniško vlogo med zaznano kakovostjo MČV in zaupanjem med športniki. To ugotovitev lahko pojasnimo tudi z logično izpeljavo, ki temelji na vlogi trenerja v športnih klubih. Glavni trener namreč izvaja večino vsakodnevnih MČV praks, ki vključujejo košarkarje, zato je zaupanje košarkarjev vanj tudi bolj odvisno od tega, kako te prakse košarkarji zaznavajo. 
Rezultati potrjujejo, da je stopnja zaupanja v timu močan napovednik kohezivnosti. Prav zaupanje med športniki znotraj tima se je namreč izkazalo kot dejavnik, ki je v najtesnejši zvezi s konstruktom kohezivnosti. V splošnem lahko ugotovimo, da je visoka stopnja zaupanja med športniki najmočnejši stimulator za kooperativno delo članov ekipe. Zaupanje v neposredno nadrejenega igra ključno vlogo posrednika tako v odnosu med zaznano kakovostjo MČV pri zaposlenih in njihovim zaupanjem $\mathrm{v}$ sodelavce, kot tudi $\mathrm{v}$ vzročno-posledični relaciji med percepcijo MČV in stopnjo kohezivnosti delovne skupine. To je v skladu s teorijo družbene izmenjave, ki pravi, da v organizacijah, kjer zaposleni preko pozitivnih MČV praks dobijo občutek, da menedžment v njihov razvoj vlaga, obstaja tudi večja pripravljenost na sprejem tveganja, kar je predpogoj za ustvarjanje odnosov zaupanja med člani organizacije. Vendar pa sama pozitivna percepcija MČV ni dovolj, da neposredno spodbudi zaupanje med sodelavci. $\mathrm{Za}$ omogočanje pozitivnega vpliva MČV je potrebno zaupanje zaposlenih $\mathrm{v}$ neposredno nadrejene oziroma $\mathrm{v}$ tiste, ki izvedejo največji del vsakodnevnih MČV praks. Le-ti lahko bistveno pripomorejo k oplemenitenju MČV sistema ali pa njegove pozitivne učinke na zaupanje med sodelavci in njihovim kohezivnim vedenjem povsem preprečijo.

\section{Zaključek}

Rezultati študije kažejo na to, da zaupanje športnikov $\mathrm{v}$ trenerja in $\mathrm{v}$ soigralce neposredno pozitivno vpliva na raven kohezivnosti tima. Na drugi strani percepcija kakovosti MČV močno neposredno pozitivno vpliva na zaupanje $\mathrm{v}$ trenerja, ne pa tudi neposredno na kohezivnost ali na zaupanje v soigralce. Kljub temu se pozitiven učinek percepcije MČ́V posredno preliva preko zaupanja športnikov v trenerja na njihovo zaupanje v soigralce, posredno pa tudi povečuje stopnjo kohezivnosti tima.

$\mathrm{Z}$ vidika prispevka stroki oz. znanosti sta ključna doprinosa te študije razvoj nove merske lestvice za percepcijo kakovosti MČV v športnih timih in argumentacija, da sta zaupanje in kohezivnost dva ključna behavioristična konstrukta, preko katerih MČV lahko deluje na uspešnost. Prispevek pojasnjuje vpliv percepcije kakovosti MČV na dve ključni razmerji zaupanja znotraj športnih ekip ter kako se ti učinki odražajo na stopnjo kohezivnosti ekipe. Obenem študija pojasnjuje večdimenzionalnost konstrukta zaupanja in analizira njegovo vlogo $\mathrm{z}$ vidika posredovanja med percepcijo kakovosti MČ $\mathrm{V}$ in timsko kohezijo.

Študija ima več praktičnih implikacij na področju menedžmenta športnih organizacij. V prvi vrsti je menedžmentu in trenerjem klubov ponujena nova lestvica za merjenje percepcije kakovosti MČV. Z vsebinskega vidika je temeljna ugotovitev, da pozitivna percepcija kakovosti MČV spodbuja zaupanje. V tem primeru se zdi, da je učinek MČV večji pri tistih razmerjih, kjer ima subjekt, v katerega merimo zaupanje, večji vpliv pri oblikovanju in izvedbi MČV praks z vidika subjekta, čigar stopnjo zaupanja merimo. Jakost analizirane vzročnoposledične povezave je odvisna od teh dveh parametrov, zato je razumljiv večji vpliv percepcije kakovosti MČV na zaupanje košarkarjev v trenerja kot na njihovo medsebojno zaupanje, saj ima ravno trener običajno več pristojnosti pri oblikovanju MČV procesa, košarkarji pa v določeni meri le sodelujejo pri njegovi izvedbi. Medtem ko sama pozitivna izkušnja glede 
kakovosti MČV ne zadostuje za ustvarjanje visoke stopnje zaupanja med člani športnega tima, niti za visoko stopnjo njegove kohezivnosti, zaupanje športnikov v glavnega trenerja pomaga transferirati učinke percepcije MČV na oba konstrukta. Te ugotovitve podpirajo trditev, da je glavni trener v tekmovalnih športnih timih veliko več kot le neposredno nadrejeni subjekt, ki bi samo izvajal navodila top menedžmenta športnega kluba. Ima namreč resnično velik manevrski prostor za oblikovanje narave $M \check{C} V$ in ima posledično moč, da prenese MČV učinke na povišanje zaupanja med športniki ter na višjo stopnjo kohezivnosti.

Med omejitve študije lahko štejemo uporabo subjektivnih podatkov, a se temu v konkretnem primeru merjenja zaupanja, kohezivnosti in percepcije kakovosti MČ́V nismo mogli izogniti. Omejitev je tudi zbiranje podatkov v samo eni časovni točki le med košarkarskimi klubi v štirih državah. Te so bile izbrane glede na pripravljenost nacionalnih košarkarskih zvez, ki so nam pomagale pri zbiranju podatkov. $Z$ vsebinskega vidika je omejitev raziskave neupoštevanje povratnih vzročnih povezav med preučevanimi spremenljivkami in še vedno velik nepojasnjen prostor na področju delovanja vzročnih povezav med HRM in zaupanjem ter med zaupanjem in kohezijo.

Priporočamo nadaljnje raziskave med športnimi klubi skozi daljše časovno obdobje, v različnih okoljih in v različnih športnih panogah. Istočasno predlagamo uvedbo novih spremenljivk v predložen paradigmatičen model, kar bo omogočilo dopolnitev ugotovitve te raziskave.

\section{Reference}

1. Adams, B. D., Waldherr, S., \& Sartori, J. (2008). Trust in Teams Scale. Trust in Leaders Scale. Manual for Administration and Analyses. Toronto: Department od National Defence.

2. Alfes, K., Truss, C., Soane, E. C., Rees, C. \& Gatenby, M. (2013). The relationship between line manager behavior, perceived HRM practices, and individual performance: examining the mediating role of engagement. Human Resource Management, 52(6), 839-859.

3. Becker, B. E., \& Huselid, M. A. (1998). High performance work systems and firm performance: A synthesis of research and managerial implications. Research in Personnel and Human Resources Journal, 16(1), 53-101.

4. Blau, M. P. (1964). Exchange and power in social life. New York: Wiley.

5. Bowen, N. K., \& Guo, S. (2011). Structural equation modeling (pocket guides to social work research methods). Oxford University Press.

6. Carron, A. V., \& Brawley, L. R. (2000). Cohesion. Conceptual and measurement issues. Small Group Research, 31(1), 89-106.

7. Carron, A. V., Bray, S. R., \& Eys, M. A. (2002). Team cohesion and team success in sport. Journal of Sport Sciences, 20(2). 119-126.

8. Carron, A. V., Widmeyer, W. N., \& Brawley, L. R. (1985). The development of an instrument to assess cohesion in sport teams: the Group Environment Questionnaire. Journal of Sport Psychology, 7(3), 244-266. 
9. Crciun, M., \& Rus, C. (2009). The relationship between perceived coach leadership behaviours and team cohesion among romanian athletes. Revista Iberoamericana de Psicología del Ejercicio y el Deporte, 4(2), 217-231.

10. Condrey, S. E. (1995). Reforming resource management system: exploring the importance of organizational trust. American Review of Public Administration, 25(4), 341-354.

11. Cropanzano, R., Prehar, C., \& Chen, P. Y. (2002). Using social exchange theory to distinguish procedural justice from interactional justice. Group and Organizational Management, 27(3), 324351.

12. Dirks, K. T. (2000). Trust in leadership and team performance: Evidence from NCAA basketball. Journal of Applied Psychology, 85(6), 1004-1012.

13. Dirks, K. T., \& Ferrin, D. L. (2001). The role of trust in organizational settings. Organization Science, 12(4), 450-467.

14. Dirks, K. T., \& Skarlicki, D. P. (2009). The relationship between being perceived as trustworthy by coworkers and individual performance. Journal of Management, 35(1), 136-157.

15. Gonçalves, S. P., \& Neves, J. (2012). The link between perception of human resource management practices and employee well-being at work. Advances in Psychology Study, 1(1), 3139.

16. Gould-Williams, J., \& Davies, F. (2005). Using social exchange theory to predict the effects of HRM practice on employee outcomes. Public Management Review, 7(1), 1-24.

17. Gulati, R. (1995). Does familiarity breed trust? The implications of repeated ties for contractual choices in alliances. Academy of Management Journal, 38(1), 85-112.

18. Hackman, J. R., \& Morris, C. G. (1975). Group tasks, group interaction process, and group performance effectiveness: A review and proposed integration. Advances in Experimental Social Psychology, 8, 45-99.

19. Hogg, M. A., Abrams, D., Otten, S. \& Hinkle, S. (2004). The social identity perspective: intergroup relations, self-conception, and small groups. Small Group Research, 35(3), 246-276.

20. Jackson, S.E., \& Schuler, R.S. (1995). Understanding human resource management in the context of organizations and their environments. Annual Review of Psychology, 46(1), 237-64.

21. Johnson-George, C., \& Swap, W. (1982). Measurement of specific interpersonal trust: Construction and validation of a scale to assess trust in a specific other. Journal of Personality and Social Psychology, 43(6), 1306-1317.

22. Laeequddin, M., Sahay, B. S., Sahay, V., \& Waheed, K. A. (2010). Measuring trust in supply chain partners' relationships. Measuring Business Excellence, 14(3), 53-69.

23. Li, F., \& Harmer, P. (1996). Confirmatory factor analysis of the Group Environment Questionnaire with an intercollegiate sample. Journal of Sport and Exercise Psychology, 18(1), 49-63.

24. Lu, L. (2015). Building trust and cohesion in virtual teams: the developmental approach. Journal of Organizational Effectiveness: People and Performance, 2(1), 55-72.

25. Mach, M., Dolan, S., \& Tzafrir, S. (2010). The differential effect of team members' trust on team performance: The mediation role of team cohesion. Journal of Occupational and Organizational Psychology, 83(3), 771-794.

26. Searle, R. H. \& Skinner, D. (2011). Trust and human resource management. Cheltenham: Edward Elgar.

27. Tzafrir, S. S. (2005). The relationship between trust, HRM practices and firm performance. International Journal of Human Resource Management, 16(9), 1600-1622. 
28. Zafirovski, M. (2005). Social exchange theory under scrutiny: a positive critique of its economicbehaviorist formulations. Electronic Journal of Sociology. Najdeno 25. Marca 2018 na spletnem naslovu:

https://www.researchgate.net/publication/228349971_Social_exchange_theory_under_scrutiny_A _positive_critique_of_its_economic-behaviorist_formulations.

29. Zaheer, A., McEvily, B., \& Perrone, V. (1998). Does trust matter? Exploring the effects of interorganizational and interpersonal trust on performance. Organization Science, 9(2), 141-159.

\section{Abstract: Trust as the Sport Team Cohesion Factor}

Research Question (RQ): What role do the trust in teammates and trust in coach have and how strong do they influence the cohesiveness of a sport team?

Purpose: The aim is to contribute to the theory of human resource management by explaining the relationships between the perception of the HRM quality, trust in co-workers and superiors, and team cohesiveness in the context of sport team. The main goal is to develop a model based on theory and test its validity in practice.

Method: The model was tested on data collected from 559 athletes from 73 basketball clubs by structural equation modelling and Sobel's test of mediation.

Results: Athletes' trust in the coach and in the teammates has direct positive effect on the team cohesiveness. The perception of the HRM quality has a strong direct positive effect on trust in the coach, but does not directly affect cohesiveness or trust in teammates. Nevertheless, the positive effect of the HRM perception indirectly spills over through the athletes' trust in coach on their trust in teammates, and indirectly also increases the team cohesiveness.

Organization: The article provides a new scale for measuring the perception of HRM quality. It reminds coaches of the importance of athletes' trust in coach, as it stimulates trust among athletes and cohesiveness.

Society: The study emphasizes the importance of interpersonal relationships and explains how people turn their trust into a sense of better connection with co-workers.

Originality: A new scale for measuring the perception of the HRM quality. It is the first study of relationships between the quality of HRM, two trust relations and team cohesiveness within sport team.

Limitations / further research: Use of subjective data and their collection in only one time point. We recommend further research between sports clubs over a longer period of time, in different environments and in different sports.

Keywords: basketball, coach, cohesiveness, HRM, team, trust.

$* * *$

Igor Ivašković je diplomiral na področju ekonomije, zgodovine, prava, južnoslovanskih jezikov ter pedagogike in andragogike, doktoriral je na področju menedžmenta in organizacije, prava in politologije. Trenutno je zaposlen kot docent na Ekonomski fakulteti Univerze v Ljubljani, raziskovalno pa se ukvarja s problematiko športnih organizacij, strateškega odločanja in zgodovino jugovzhodne Evrope.

Copyright (c) Igor IVAŠKOVIĆ

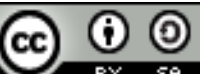

Creative Commons License

This work is licensed under a Creative Commons Attribution-ShareAlike 4.0 International License. 